\title{
PENGETAHUAN DAN SIKAP IBU TENTANG PEMBERIAN IMUNISASI BCG PADA BAYI DI KLINIK PRATAMA HANAFI MEDAN
}

\author{
Fatwiany ${ }^{1}$ \\ ${ }^{1}$ STIKes Sehat Medan, Medan \\ Email: ${ }^{1}$ wie.ranaya@gmail.com
}

\begin{abstract}
Abstrak
Imunisasi Bacille Calmette Guerin (BCG) adalah penyuntikan vaksin BCG pada bayi yang bertujuan untuk membentuk kekebalan aktif terhadap penyakit tuberkulosis. Penelitian ini bertujuan untuk mengetahui gambaran pengetahuan ibu tentang pemberian imunisasi BCG pada bayi di Klinik Pratama Hanafi Medan. Penelitian ini menggunakan metode penelitian deskriptif dengan metode pengambilan sampel Accidental sampling. Populasi penelitian ini adalah ibu yang mempunyai bayi berusia 0 - 12 bulan di wilayah kerja Klinik Pratama Hanafi Medan. Hasil penelitian ini menunjukkan bahwa dari 40 responden, pengetahuan responden tentang pemberian imunisasi BCG pada bayi dengan kategori baik adalah 17 responden $(57,5 \%)$ dan yang memiliki pengetahuan kurang sebanyak 17 responden (42,5\%). Sikap menerima responden terhadap pemberian imunisasi BCGpada bayi dengan kategori menerima adalah 36 responden (90\%) dan jumlah responden yang tidak menerima sebanyak 4 responden (10\%). Dapat disimpulkan bahwa pengetahuan ibu mengenai pemberian imunisasiBCG pada bayi lebih banyak dengan kategori kurang. Sikap responden tentang pemberian imunisasi BCG pada bayi paling banyak dengan kategori menerima.
\end{abstract}

Kata kunci: Imunisasi; BCG; Pengetahuan

\begin{abstract}
Bacille Calmette Guerin (BCG) immunization is an injection of the BCG vaccine in infants which aims to form active immunity against tuberculosis. This study aims to describe the knowledge of mothers about giving BCG immunization to infants at the Hanafi Pratama Clinic, Medan. This research used descriptive research method with accidental sampling method. The population of this study were mothers who had babies aged 0-12 months in the working area of the Pratama Hanafi Clinic, Medan. The results of this study indicate that of the 40 respondents, the knowledge of respondents about giving BCG immunization to infants with good categories was 17 respondents $(57.5 \%)$ and those who had less knowledge were 17 respondents $(42.5 \%)$. The respondent's attitude towards giving BCG immunization to infants in the category of receiving was 36 respondents (90\%) and the number of respondents who did not receive it was 4 respondents (10\%). It can be concluded that mother's knowledge about giving BCG immunization to babies is more with less category. Respondents' attitudes about giving BCG immunization to infants were mostly in the category of receiving.
\end{abstract}

Keywords: Immunization; BCG; Knowledge

\section{Pendahuluan}

Penyakit tuberculosis masih merupakan masalah utama kesehatan masyarakat dan penyebab utama kematian nomor 1 untuk penyakit infeksi di Indonesia. WHO menyatakan bahwa, Indonesia merupakan penyumbang terbesar nomor 3 di dunia. Jumlah kasus TBC 
pada anak di Indonesia sekitar seperlima dari seluruh kasus TBC (Marmi, Kukuh Raharjo, 2015). Indonesia berpeluang mencapai penurunan angka kesakitan dan kematian akibat TB menjadi setengahnya di tahun 2015 jika dibandingkan dengan data tahun 1990. Angka prevalensi TB yang pada tahun 1990 sebesar 443 per 100.000 penduduk, pada tahun 2015 ditargetkan menjadi 280 per 100.000 penduduk. Berdasarkan hasil survei prevalensi TB Tahun 2013, Prevalensi TB paru smear positif per 100.000 penduduk umur 15 tahun ke atas sebesar 257 (1). Angka riotifikasi kasus menggambarkan cakupan penemuan kasus TB. Secara umum angka notifikasi kasus BTA positif baru dan semua kasus dan tahun ke tahun di Indonesia mengalami peningkatan. Angka notifikasi kasus (Case Notification Rote/CNR) pada tahun 2015 untuk semua kasus sebesar 117 per 100.00 penduduk (Tangkilisan, 2020).

Imunisasi sebagai salah satu pencegahan upaya preventif yang berdampak positif terhadap kesehatan masyarakat harus dilaksanakan secara terus-menerus, menyeluruh, dan sesuai standar sehingga mampu memutus mata rantai penularan penyakit serta menimbulkan/meningkatkan kekebalan seseorang secara aktif terhadap suatu penyakit. Imunisasi merupakan salah satu intervensi kesehatan yang terbukti paling cost effective (murah), karena dapat mencegah dan mengurangi kejadian kesakitan, kecacatan, dan kematian akibat penyakit menular yang diperkirakan 2 hingga 3 juta kematian tiap tahunnya (kemenkes, 2018). Imunisasi BCG memiliki manfaat untuk mencegah TBC, yang merupakan penyakit menular dan menyerang organ tubuh terutama paru-paru. Disebabkan oleh basil batang yaitu Mycobacterium tuberculosis (WHO and IDAI, 2013). Bakteri tersebut juga menyerang organ tubuh seperti tulang sendi, usus, kelenjar limfa, dan selaput otak. Penyakit TBC menular apabila seseorang menghirup udara yang tercemar bakteri Mycobacterium tuberculosis yang dilepaskan pada saat penderita TBC batuk (Harrison et al., 2016).

Manfaat imunisasi Basil Calmette Guerin adalah mencegah bayi atau anak terserang dari penyakit TBC yang berat, seperti: meningitis TBC dan TBC milier. Ini dikarenakan bayi atau anak masih rentan terinfeksi Mycobacterium Tuberculosis penyebab penyakit TBC, akibat adanya kontak dengan penderita TBC yang ada di sekitarnya, seperti: orang tua, keluarga, pengasuh, dan lain (Rivanica dan Hartina, 2020).

Tingkat pendidikan, pengetahuan memiliki pengaruh dalam pencapaian cakupan imunisasi bcg. Ibu bayi yang memiliki pendidikan tinggi memiliki kemungkinan lebih besar untuk memberikan imunisasi bcg dibandingkan ibu berpendidikan rendah (Wulansari dan Nadjib, 2019). Sikap Ibu terhadap pemberian imunisasi juga berpengaruh secara signifikan terhadap cakupan imunisasi dasar lengkap. Ibu yang memiliki sikap negatif tentang imunisasi lebih besar kemungkinannya tidak memberikan imunisasi lengkap pada bayinya dari pada ibu yang memiliki sikap positif (Kharin, 2021).

Hasil survey pendahuluan yang dilakukan dengan wawancara pada 8 orang ibu yang berkunjung ke Klinik, 6 orang ibu mengatakan mengimunisasi BCG anaknya karena jadwal yang diberikan bidan, 2 orang ibu mengatakan anaknya sakit sehingga jadwal imunisasi BCG bayinya tidak tepat. Berdasarkan uraian diatas maka peneliti tertarik untuk meneliti Pengetahuan dan Sikap Ibu tentang Pemberian Imunisasi BCG pada bayi di klinik Pratama Hanafi. 


\section{Metode Penelitian}

Penelitian deskriptif dimana penelitian menguraikan atau memberi gambaran atau diskripsi tentang suatu keadaan secara objektif mengenai Pemberian Imunisasi BCG Di Klinik Pratama Hanafi. Populasi pada penelitian ini adalah keseluruhan ibu yang memiliki bayi 02 bulan di Klinik Pratama Hanafi dengan teknik Accidental Sampling yaitu sebanyak 40 orang.

\section{Hasil dan Pembahasan}

\section{Hasil Penelitian}

Berdasarkan penelitian yang dilakukan terhadap 40 responden mengenai Pengetahuan Dan Sikap Ibu Menyusui Terhadap Pemberian Imunisasi BCG pada Bayi Di Klinik Pratama Hanafi Medan yang disajikan dalam bentuk narasi, tabel dan dibahas menurut tujuan dari penelitian.

Tabel 1. Karakteristik Responden

\begin{tabular}{lccc}
\hline & Karakteristik & Frekuensi & $\%$ \\
\hline 1. & Umur & & \\
& $\leq 25$ & 10 & 25 \\
& $26-30$ & 20 & 50 \\
& $>30$ & 10 & 25 \\
\hline Total & 40 & 100 \\
\hline 2. Pendidikan & & \\
& SD & 12 & 30 \\
& SMP & 10 & 25 \\
& SMA & 8 & 20 \\
& Diploma & 5 & 12.5 \\
& S1 & 5 & 12.5 \\
\hline Total & 40 & 100 \\
\hline 3. Pekerjaan & & \\
\hline & IRT & 20 & 50 \\
& Wiraswasta & 15 & 37.5 \\
& PNS & 5 & 12.5 \\
\hline & Total & 40 & 100 \\
\hline
\end{tabular}

Berdasarkan tabel 1 diperoleh hasil dari 40 responden sebanyak 20 responden $(50, \%)$ memiliki umur 26-30 tahun. Berdasarkan Pendidikan responden terbanyak berada pada tingkat Pendidikan SMP yaitu 10 orang $(25 \%)$ sedangkan dilihat dari pekerjaan sebanyak 20 responden (50\%) ibu rumah tangga.

Tabel 2 Pengetahuan Responden Tentang Pemberian Imunisasi BCG Pada Bayi Di Klinik pratama Hanafi Medan

\begin{tabular}{ccc}
\hline Pengetahuan & Frekuensi & Presentase (\%) \\
\hline Baik & 23 & 57.5 \\
Kurang & 17 & 42.5 \\
Jumlah & 40 & 100 \\
\hline
\end{tabular}


Tabel 2 diatas menunjukkan bahwa dari 40 responden, dapat diketahui jumlah responden yang memiliki jumlah pengetahuan kurang tentang pemberian imunisasi BCG pada bayi adalah sebanyak 23 responden $(57,5 \%)$, dan jumlah responden yang memiliki pengetahuan baik tentang pemberian imunisasi BCG pada bayi sebanyak 17 responden $(42,5 \%)$.

Tabel 3. Sikap Responden Terhadap Pemberian Imunisasi BCG Pada Bayi Di Klinik Pratama Hanafi Medan

\begin{tabular}{ccc}
\hline Sikap & Frekuensi & Presentase (\%) \\
\hline Menerima & 36 & 90. \\
Tidak Menerima & 4 & 10 \\
Jumlah & 40 & 100 \\
\hline
\end{tabular}

Berdasarkan tabel 3 diatas menunjukkan bahwa bahwa 40 responden, diketahui jumlah responden yang memliki sikap menerima terhadap pemberian imunisasi BCG pada bayi sebanyak 30 responden (90\%), jumlah responden yang tidak menerima tentang pemberian imunisasi BCG pada bayi adalah sebanyak 10 responden (10\%).

\section{Pembahasan}

Pemberian imunisasi BCG dijadwalkan pada bayi berusia 0-2 bulan. Dengan manfaat mencegah terjadinya TBC, Dimana penyakit ini menyerang paru yang memiliki gejala batuk berat. Infeksi pada paru akan mengganggu proses pernafasan dan kecukupan oksigen bagi tubuh. Akibat infeksi paru ini bisa berujung pada kematian. Selain berbahaya, tuberkulosis juga cepat menular dengan percikan batuk penderita di udara. Sehingga menyebabkan penyebaran penyakit lebih gampang pada orang lain. Selain itu dapat dinyatakan bahwa, ibu yang tidak memberikan imunisasi BCG pada bayi usia 0-2 bulan memberikan dampak pada penyumbang angka kejadian TBC. Jika bayi tidak diberikan imunisasi maka anaknya akan memiliki resiko lebih besar terkena TBC, bahkan dapat terkena TBC yang lebih berat. Pemberian imunisasi tepat pada waktuya akan mengurangi dampak buruk dari penyakit yang berkaitan dengan vaksinasi tersebut. Walaupun ada kemungkinan terkena kuman namun gejala penyakit akan lebih ringan (Senewe dkk, 2017).

Peran seorang ibu pada program imunisasi sangatlah penting. Karenanya suatu pemahaman tentang program ini amat diperlukan untuk kalangan tersebut. Pemahaman ibu atau pengetahuan ibu tentang bimunisasi sangat dipengaruhi oleh banyak faktor. Dan Dalam penentuan sikap ini, tingkat pengetahuan, cara berfikir, keyakinan, dan emosi memegang peranan penting. Pada penelitian ini dapat dilihat gambaran ibu yang memiliki bayi di klinik Hanafi dengan mayoritas umur 50\% berusia 26-30 tahun, tingkat pendidikan mayoritas SMP 25\%, mayoritas ibu rumah tangga 50\%, dengan pengetahuan baik sebanyak 57,5\% tetapi sikap menerima imunisasi BCG sebanyak $90 \%$.

Sejalan dengan penelitian yang dilakukan oleh Yulinda, dkk (2020) dalam penelitiannya tentang pengetahuan dan sikap orang tua dalam pemberian BCG menyatakan bahwa mayoritas berpengetahuan kurang yaitu sebanyak 39 responden $(46,4 \%)$ Berdasarkan sikap mayoritas bersikap positif yaitu sebanyak 60 responden $(71,4 \%)$. Yeni (2021) dalam penelitiannya juga mneyatakan bahwa Dalam penentuan 
sikap ini, tingkat pengetahuan, cara berfikir, keyakinan, dan emosi memegang peranan penting dalam pemberian imunisasai bcg pada bayi.

Hasil penelitian yang diperoleh terkait dan kejadian di lapangan maka peneliti berasumsi bahwa usia, pengetahuan dan lingkungan seseorang mempengaruhi cara berfikir, bersikap dan bagaimana kemampuan seseorang untuk dapat menerima informasi sehingga orang tersebut mampu bersikap sesuai dengan informasi dan pengetahuan yang ia dapatkan.

\section{Kesimpulan}

Pengetahuan Ibu tentang imunisasi BCG baik adalah sebanyak 24 responden $(52,7 \%)$, dan yang memiliki pengetahuan kurang sebanyak 16 responden (47.3\%). Sikap menerima terhadap pemberian imunisasi BCG pada bayi sebanyak 30 responden $(90,32 \%)$ dan jumlah responden yang tidak menerima adalah sebanyak10 responden $(9,68 \%)$.

\section{Referensi}

Ariyani, F. (2019). Hubungan Pengetahuan Dan Sikap Ibu Tentang Imunisasi Bcg Dengan Pemberian Imunisasi Bcg Pada Bayi Usia 0-2 Bulan Di Puskesmas Pauh Padang. Jurnal Kesehatan Mercusuar, 2(1), 7-7

Harrison, M. S. et al.(2016)'Pathways to preterm birth: Case definition and guidelines for data collection, analysis, and presentation of immunization safety data', Vaccine. doi: 10.1016/j.vaccine.2016.03.054

Kharin, A. N. (2021). Pengetahuan, Pendidikan, Dan Sikap Ibu Terhadap Imunisasi Dasar Lengkap Di Kabupaten Bogor. Pengmaskesmas: Jurnal Pengabdian Kesehatan Masyarakat, 1(1).

Marmi, Kukuh Raharjo (2015). Asuhan Neonates Bayi, Balita Dan Prasekolah. Yogjakarta : Pustaka Pelajar

Rivanica, R., Hartina, i., (2020). Pemberian Imunisasi Bcg Pada Bayi (1-3 Bulan) Berdasarkan Tingkat Pengetahuan Dan Sikap Ibu. Jurnal 'Aisyiyah Medika, 5(1), 205-212.

RI Kemenkes. Profil Kesehatan Indonesia Tahun 2017. Jakarta Kementeri Kesehat Ri. $2018 ; 170-3$

Senewe, M. S., Rompas, S. and Lolong, J. (2017) 'Analisis Faktor yang berhubungan dengan Kepatuhan Inu Dalam Pemberian Imunisasi Dasar di Puskesmas’, jurnal ilmu keperawatan, 5, pp. 1-12.

Tangkilisan Jra, Langi Flfg, Kalesaran Afc. Angka Penemuan Kasus Tuberkulosis Paru di Indonesia Tahun 2015-2018. Kesmas. 2020;9(5)

WHO and IDAI (2013) 'Pelayanan kesehatan anak di rumah sakit',Kesehatan, 2(pelayanan 
masyarakat), p. 2. Available at: http://gooleknah.nmetreisnbs.

Wulansari \& Nadjib, M. (2019). Determinan Cakupan Imunisasi Dasar Lengkap pada Penerima Program Keluarga Harapan. Jurnal Ekonomi Kesehatan Indonesia. 4(1).

Yeni Arpah, Y. A. (2021). Hubungan Pengetahuan Dan Sikap Ibu Dengan Kelengkapan Imunisasi Dasar Di Uptd Puskesmas Sukaraya Kecamatan Baturaja Timur Tahun 2021 (Doctoral Dissertation, Stik Bina Husada Palembang). 